Historic, Archive Document

Do not assume content reflects current scientific knowledge, policies, or practices. 

62.97

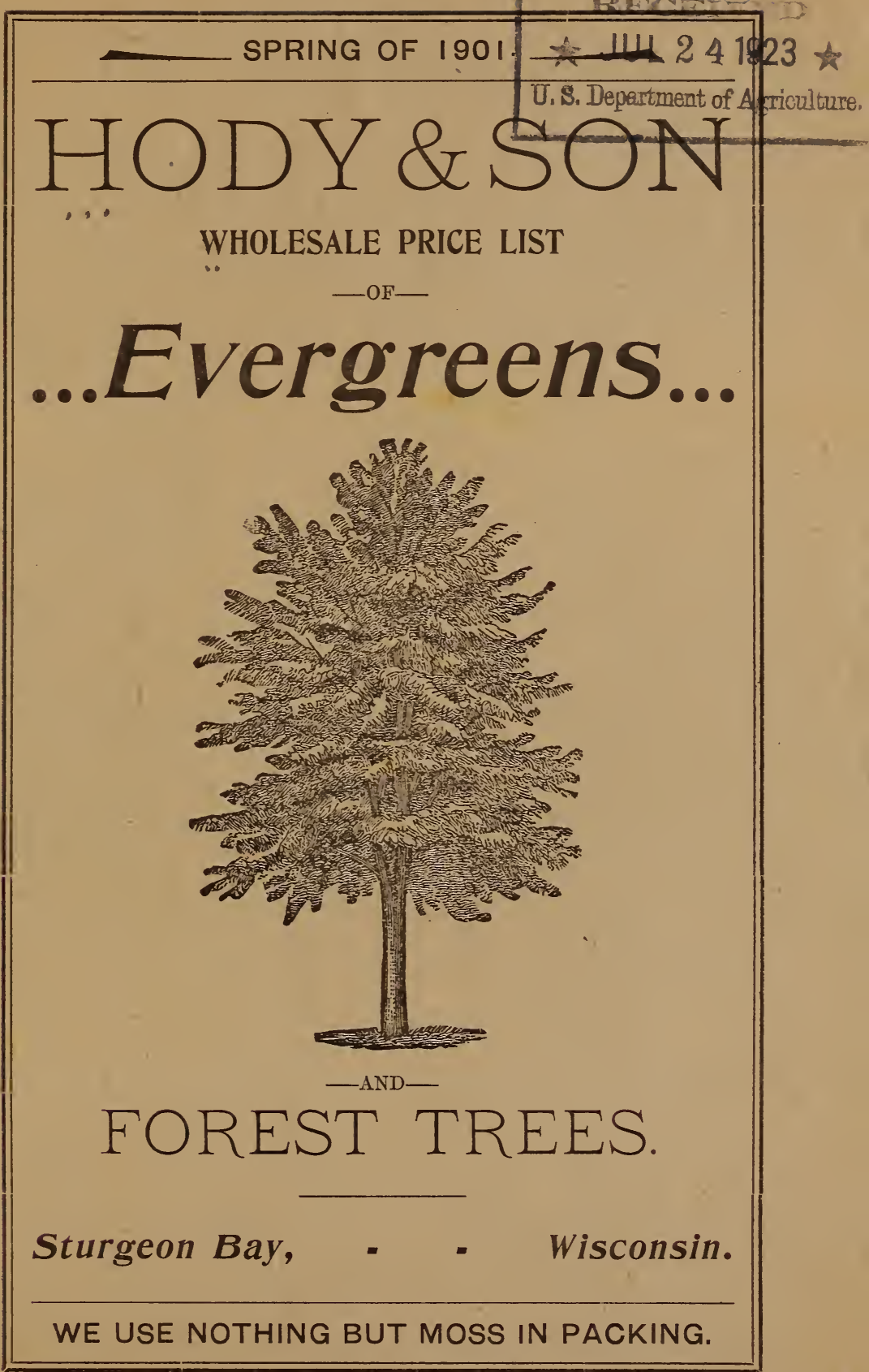




\section{Wholesale Price List.}

ARBOR VITE-

Each,

4 to 8 inches.

02

8 to 12 inches....................... 03

12 to 18 inches........................... 04

18 to 24 inches $\ldots \ldots \ldots \ldots \ldots \ldots \ldots \ldots, 06$

2 to 3 feet $\ldots \ldots \ldots \ldots \ldots \ldots \ldots \ldots . . . . . . . .10$

3 to 5 feet.............................. 25

Transplanted 1 yr., 4 to 8 in. $\ldots \ldots \ldots . . .04$

FIR-BALSAMI-

4 to 8 inches..................... $0 ;$

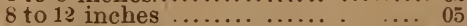

12 to 18 inches ..................... 06

18 to 24 inches $\ldots \ldots \ldots \ldots \ldots \ldots \ldots \ldots \ldots . . .10$

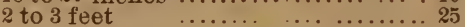

Transplanted 1 yr., 4 to 8 in ........... 05

8 to 12 in. ......... 08

PINE-White-

4 to 6 inches .................. 02

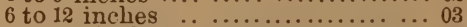

12 to 18 inches...................... 04

18 to 24 inches........................ 10

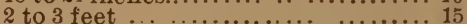

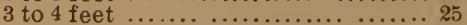

SPRUCE-WHITE-

4 to 12 inches................... 03

8 to 12 inches ........................... 04

12 to 18 inclies.............................. 10

HEMLOCK-

4 to 8 inches.................. 01

8 to 12 inches.... ......................... 01

12 to 14 inches ...................... 02

18 to 24 inches ... . ..................... 03

2 to 3 feet ............................ 15

ASH-BuACK-

4 to 8 inches ................... 03

8 to 15 inches ...................... 06

15 to 24 inches . . ................. 08

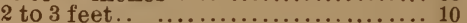

3 to 4 feet $\ldots \ldots \ldots \ldots \ldots \ldots \ldots \ldots \ldots \ldots \ldots . \ldots \ldots$

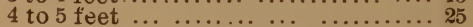

YEW-ANIERICAN-

8 to 15 inches $. . \ldots \ldots \ldots \ldots \ldots \ldots . \ldots . \ldots 5$

15 to 24 inches ......................... 15

BEECH-A ArERICAN-

4 to 8 inches $\ldots \ldots \ldots \ldots \ldots, \ldots \ldots \ldots, 02$

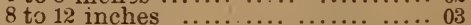

15 to 24 inches ..................... 04

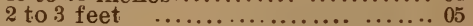

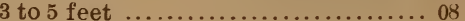

5 to 7 feet ..................... 25

$\begin{array}{rrr}10 . & 100 . & 1000 \\ .04 & .30 & 2.00 \\ .06 & .40 & 3.00 \\ .08 & .70 & 6.00 \\ .20 & 1.50 & 1200 \\ .50 & 300 & 25.00 \\ 1.50 & 10.00 & \cdots \cdots \\ .25 & 2.00 & \cdots \cdots \\ .35 & 3.00 & \cdots \cdots \\ & & \\ .04 & .30 & 2.00 \\ .10 & .50 & 6.00 \\ .15 & 1.00 & 8.00 \\ .20 & 1.50 & 12.00 \\ .75 & 2.50 & \cdots \cdots \\ .40 & 3.00 & \cdots \cdots \\ .65 & 4.00 & \cdots \cdots\end{array}$

.10

.15

.25

.50

1.50

$.80 \quad 7.00$

$1.25 \quad 10.00$

$1.75 \quad 15.00$

$2.50 \quad 20.00$

5.00

$\therefore$

$\begin{array}{lll}.20 & 1.50 & 12.00 \\ .25 & 1.75 & 14.00 \\ .50 & 2.50 & 20.00\end{array}$

$\begin{array}{lll}.06 & .45 & 4.00\end{array}$

$\begin{array}{rrr}.09 & .70 & 6.00 \\ .12 & .90 & 8.00\end{array}$

$\begin{array}{llr}.15 & 125 & 10.00\end{array}$

$\begin{array}{lll}.50 & 5.00 \quad \ldots .\end{array}$

$\begin{array}{rrr}.12 & .40 & 325 \\ .30 & .78 & 5.75 \\ .40 & 1.50 & 12.00 \\ .60 & 3.00 & 20.00 \\ .75 & 4.00 & 30.00 \\ 1.00 & 5.00 & 40.00\end{array}$

$.50 \quad 2.50$

$\begin{array}{ll}.50 & 2.50 \\ .75 & 5.00\end{array}$

.10

.10

.150

.75

$.30 \quad 2.00$

.50

3.00

5.00

3.50
10,00

25.00

1.75

12.50

90.00

BIRCH-AMERICAN AND Yellow-

8 to 15 inches ....................... 02

15 to 24 inches.......................... 04

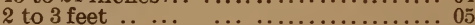

3 to 5 feet......................... 06

5 to 7 feet.................................. 10

$\begin{array}{rrr}.10 & .45 & 3.50 \\ .15 & .85 & 6.00 \\ .30 & 1.50 & 10.00 \\ .50 & 3.50 & 25.00 \\ .80 & 7.00 & 50.00\end{array}$

LEATHERWOOD-MOOSEWOOD -

2 feet .......................... 25

2.00

12.00

\section{COTTONWOOD-YELLOW-}

6 to 12 inches $\ldots \ldots \ldots \ldots \ldots \ldots \ldots \ldots, \ldots \ldots, \ldots \ldots$

12 to 24 inches $\ldots \ldots \ldots \ldots \ldots \ldots \ldots \ldots \ldots \ldots \ldots \ldots \ldots, 05$

2 to 3 feet.............................. 08

3 to 5 feet............................ 10

5 to $\mathrm{r}$ feet....................... 15

$\begin{array}{lr}.10 & .25 \\ .15 & .40 \\ .20 & .75 \\ .40 & 1.00 \\ .75 & 2.00\end{array}$

1.00

2.00

4.00

600

12.50 


\begin{tabular}{|c|c|c|c|}
\hline 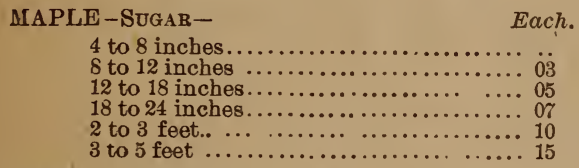 & $\begin{array}{l}10 . \\
.05 \\
.10 \\
.15 \\
.20 \\
.40 \\
.60\end{array}$ & $\begin{array}{l}100 . \\
.20 \\
.50 \\
.75 \\
1.25 \\
2.00 \\
3.50\end{array}$ & $\begin{array}{r}1000 . \\
1.25 \\
3.50 \\
6.00 \\
9.00 \\
17.50 \\
30.00\end{array}$ \\
\hline 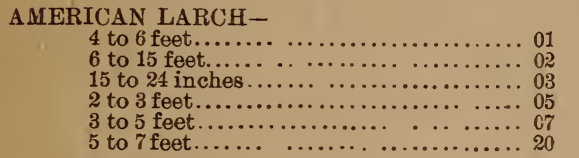 & $\begin{array}{r}.05 \\
.10 \\
.14 \\
.25 \\
.50 \\
1.50\end{array}$ & $\begin{array}{r}.15 \\
.40 \\
.80 \\
2.00 \\
3.50 \\
10.00\end{array}$ & $\begin{array}{r}2.00 \\
3.00 \\
6.00 \\
1500 \\
25.00 \\
75.00\end{array}$ \\
\hline 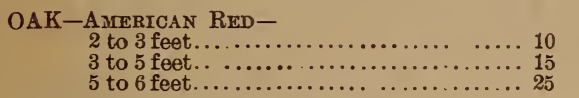 & $\begin{array}{r}.80 \\
1.50 \\
2.00\end{array}$ & $\begin{array}{r}7.00 \\
12.00 \\
18.00\end{array}$ & \\
\hline 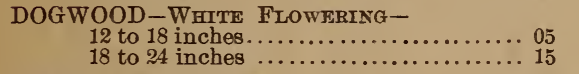 & $\begin{array}{r}.50 \\
1.00\end{array}$ & $\begin{array}{l}2.50 \\
5.00\end{array}$ & \\
\hline $\begin{array}{l}\text { SNOWBERRY-WHITE }- \\
2 \text { to } 3 \text { feet........................... } 25\end{array}$ & 2.00 & 15.00 & .... \\
\hline $\begin{array}{c}\text { FERN-Matden HaIr } \ldots \ldots \ldots \ldots \ldots \ldots \ldots \ldots . \ldots \ldots \ldots \ldots \\
\text { LaBge Leated - Grow } 2 \text { to } 4 \mathrm{ft} \text {. high- }\end{array}$ & .90 & 1000 & ..... \\
\hline handsome for pot culture............. 25 & .90 & 10.00 & .... \\
\hline GOLDEN ROD ........ & .40 & 2.50 & $\ldots \ldots$ \\
\hline CRANBERRY VINE CUTTINGS.... & & & $\cdots \cdots$ \\
\hline \multicolumn{4}{|c|}{ 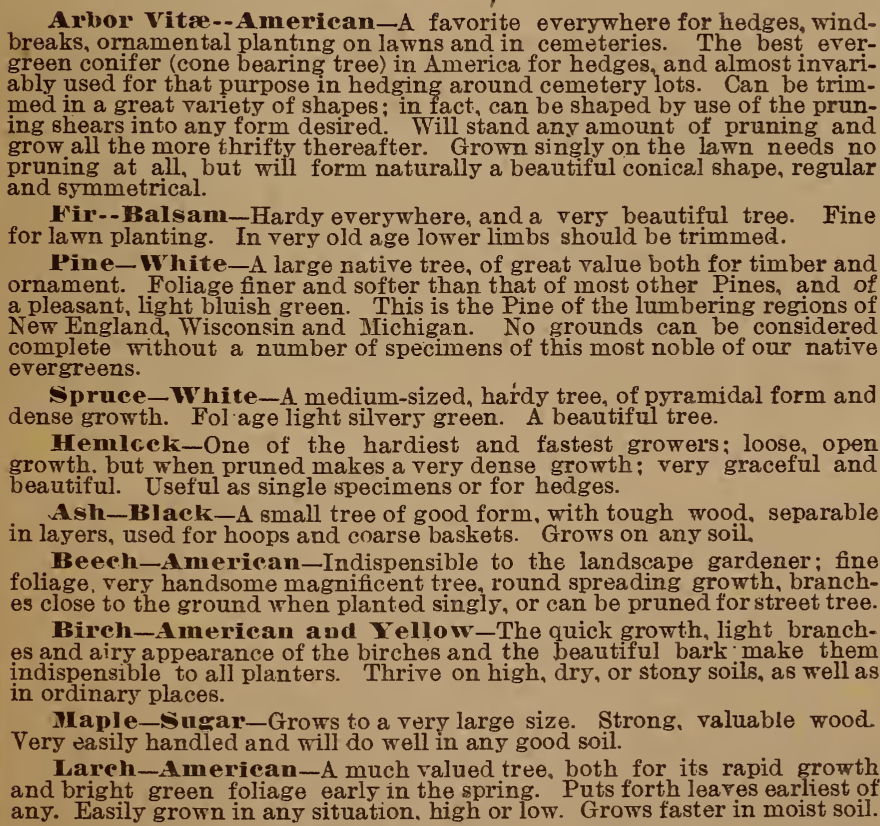 } \\
\hline
\end{tabular}




\section{PLEASE READ CAREFULL.Y}

Shipping Seasou.

In Spring our shipping season varies some, but generally begins about April 1st and continues to June 1st. All stock is dug fresh just before shipments.

Terms. Cash before shipment unless special agreement has been made for other terms of payment. C. O. D. orders must be accompanied by a sufficient sum to prepay charges both ways, or an express or freight agent's certificate must accompany order, guaranteeing that all charges will be paid by purchaser and that if goods are refused they will be returned to us free of all transportation charges. No C. O. D. orders accepted on any terms. It is not advisable for parties living in far away states to order large trees or any considerable quantity of small trees to be sent by express without having first ascertained how much the express charges will amount to. The return charges on C. O. D. freight or express shipments must be paid by the customer. Shipments to points on railroads where there is no station agent must be prepaid by us, and in such cases the amount of freight should be included in the remittance for order.

Remittances may be made by Express Money Order, Postal Money Order or by Registered Letter. One and two-cent Stamps acceptable for all amounts under $\$ 5$ when it is more conven-. ient for the remitter to send in that way. Customers must take upon themselves all risk of loss of currency or stamps sent in ordinary letters.

Order Early to be sure of having your stock at the time wanted.

Guarantee. Our responsibility ceases when delivery is made by us at postoffice, express office or freight office. We do not guarantee stock to live-no firm doing business on sound principles can give such guarantee-we Do guarantee stock to be full count and true to name and in healthy growing condition when delivered to the transportation company, and to be thoroughly packed in the best possible manner.

Shipping State distinctly whether you want the goods sent Directions. by freight or express and tell us what $R$. $R$. to ship by if you have a preference. Write your name plainly and give name of freight or express office if different from postoffice. No order accepted for less than one dollar. You may be told that the reason our prices are so low is that our stock is not worth much. Send for some specimens of our list and you can see the quality of our stock.

For Reference address the Bank of Sturgeon Bay, Sturgeon Bay, Wisconsin.

HODY \& SON, Sturgeon Bay, Wis. 